\title{
Zymosan-a Protects the Hematopoietic System from Radiation-Induced Damage by Targeting TLR2 Signaling Pathway
}

\author{
Jicong Du Ying Cheng Suhe Dong Pei Zhang Jiaming Guo Jiaqi Han \\ Fu Gao Hainan Zhao Ding Sun Jianguo Cui Jianming Cai Cong Liu \\ Department of Radiation Medicine, Faculty of Naval Medicine, Second Military Medical University, \\ Shanghai, PR China
}

\section{Key Words}

Zymosan-A • Radiation • Hematopoietic system • TLR2 • IL-6

\begin{abstract}
Background/Aims: The hematopoietic system is vulnerable to ionizing radiation and is often severely damaged by radiation. Molecules affecting radioresistance include Toll-like receptor 2. We investigated whether Zymosan-A, a novel TLR2 agonist, can protect the hematopoietic system from radiation-induced damage after total body irradiation. Methods: Mice were exposed to total body radiation after treatment with Zymosan-A or normal saline, and their survival was recorded. Tissue damage was evaluated by hematoxylin-eosin staining. The number of nucleated cells in bone marrow was determined by flow cytometry. Cell viability and apoptosis assay were determined by CCK-8 assay and flow cytometry assay. Enzymelinked immunosorbent assay was used to detect the level of cytokines. Results: Zymosan-A protected mice from radiation-induced death and prevented radiation-induced hematopoietic system damage. Zymosan-A also promoted cell viability and inhibited cell apoptosis caused by radiation, induced radioprotective effects via TLR2, upregulated IL-6, IL-11, IL-12, and TNF- $\alpha$ in vivo. Conclusion: Zymosan-A can provide protection against radiation-induced hematopoietic system damage by targeting the TLR2 signaling pathway. Thus, Zymosan-A can be potentially effective radioprotectant.
\end{abstract}

\section{Introduction}

Most patients with tumor receive radiotherapy [1-3]. Inevitable radiotherapy at different doses causes injury to normal tissues and affects tumor cells. The bone marrow hematopoietic system is the most sensitive system in the human body $[4,5]$. This sensitivity limits the use of radiotherapy in patients with tumor. Thus, novel and effective radioprotective drugs need to be developed [6-9].

J. Du, Y. Cheng and S. Dong are contributed equally to this work.

Jianming Cai, and Cong Liu

KARGER
Department of Radiation Medicine, Second Military Medical University, 800, Xiangyin Road 200433, Shanghai (P.R. China)

E-Mail caijianming882003@163.com/victorliu20102020@smmu.edu.cn/victorliu20102020@163.com 
Du et al.: Zymosan-a Protects the Hematopoietic System from Radiation-Induced Damage by Targeting TLR2 Signaling Pathway

Toll-like receptors(TLRs) have an essential role in the progress of innate immune responses [10-13]. In 2008, Burdelya et al. reported that the agonist of TLR5 exerted strong radioprotective effects on mice [14]. We then proved that TLR2, TLR4, and TLR9 also play important roles in radioresistance [15-17]. In previous studies, we proved that Pam3CSK4 and HKMT, agonists of TLR2, exhibited significant radioprotective effects on mice $[15,18]$.

Zymosan-A, which is extracted from the cell wall of yeast (Saccharomyces cerevisiae), has been demonstrated as a potent ligand of TLR2[19, 20]. Zymosan-A can activate mitogenactivated protein kinases and nuclear factor-kappa B (NF-кB)[19]. However, it was used to induce an inflammation model for multiple organ dysfunction syndrome in many studies [20-23]. In the present study, we demonstrated that Zymosan-A can also provide protection against radiation-induced hematopoietic system damage by targeting the TLR2 signaling pathway after total body irradiation.

\section{Materials and Methods}

\section{Chemicals and reagents.}

Zymosan-A was purchased from Sigma-Aldrich Corp (St. Louis, MO, USA), and normal saline (NS) was obtained from ChangHai Hospital (Shanghai, China). The apoptosis detection kit was purchased from Invitrogen (Carlsbad, California, USA), and RPMI1640 and fetal bovine serum were supplied by PAA Laboratories. Cell Counting Kit-8 (CCK-8) was purchased from Dojindo.

\section{Animals and treatment.}

Male wild-type C57BL/6 mice aged 6-8 weeks old were purchased from China Academy of Science (Shanghai, China). TLR2-/- and TLR4-/- mice were purchased from Model Animal Research Center, Nanjing University. All mice were housed in a laboratory animal room under standard conditions. The experiments were approved by the Laboratory Animal Center of the Second Military Medical University, China in conformance with the National Institute of Health Guide for the Care and Use of Laboratory Animals. The mice were treated with Zymosan-A (50 mg/Kg, dissolved in NS) via peritoneal injection 24 and $2 \mathrm{~h}$ before irradiation. The mice were killed by cervical dislocation after radiation.

\section{Cell culture and treatment.}

Human intestinal epithelial cell (HIEC) and human B lymphocyte (AHH-1) were obtained from American Type Culture Collection, and cultured in RPMI 1640 with $10 \% \mathrm{FBS}$ at $37^{\circ} \mathrm{C}$ in a $5 \% \mathrm{CO} 2$ humidified chamber. Cells were treated with Zymosan-A $(40 \mu \mathrm{g} / \mathrm{mL}) 12$ and $2 \mathrm{~h}$ before irradiation.

\section{Irradiation.}

${ }^{60} \mathrm{Co}$ source in the radiation center (Faculty of Naval Medicine, Second Military Medical University, China) was used to irradiate mice and cells. Mice were irradiated at the following doses: 7.0, 7.5, 8.5, and 9.0 Gy. Cell lines were irradiated at doses of 4 and 8 Gy.

\section{Cell viability and apoptosis assay.}

Cell viability was analyzed by CCK-8. Pretreated cells were seeded into 96-well plates at 5000 cells/ well. The cells were counted by absorbance measurements at $450 \mathrm{~nm} 24 \mathrm{~h}$ post-radiation. The cell apoptosis was analyzed using the apoptosis detection kit (Invitrogen, Carlsbad, California, USA). After radiation, the cells were stained using Annexin V-fluorescein isothiocyanate(AV-FITC) and propidium iodide (PI). The cells were then analyzed by flow cytometry (Beckman Cytoflex) in accordance with the manufacturer's instructions.

Number of white blood cells (WBCs) and bone marrow cells (BMCs) and spleen coefficient.

The number of WBCs was obtained by blood cell analysis (Mindray), and the relative number of BMCs was determined by flow cytometry (Beckman Cytoflex). The spleen coefficient was calculated as the ratio of spleen weight $(\mathrm{g})$ to body weight ( $\mathrm{g}$ ) (spleen weight/body weight). 
Bone marrow histological examination.

Mouse femurs were removed and then fixed in $4 \%$ paraformaldehyde at 1, 5, 10, 15, and $30 \mathrm{~d}$ postirradiation. The cells were then stained with hematoxylin and eosin (HE).

Enzyme-linked immunosorbent assay (ELISA)

Blood was collected from the mice $24 \mathrm{~h}$ post-irradiation and stored at room temperature for $30 \mathrm{~min}$. The blood was then centrifugated at $3000 \mathrm{rpm} / \mathrm{min}$ for $10 \mathrm{~min}$. Serum was then collected and stored at -20 ${ }^{\circ} \mathrm{C}$. The levels of IL-6, IL-11, IL-12, and TNF- $\alpha$ were analyzed by ELISA. All steps were operated as instructed.

\section{Statistical analysis.}

Data were expressed as means \pm the standard errors of means. Two-tailed Student's t-test was used to analyze the difference between 2 groups. ANOVA was employed to analyze the difference among 3 groups. Kaplan-Meier analysis was applied to estimate the difference of overall survival between 2 groups. The data were analyzed using SPSS ver. 19 (IBM Corp., Armonk, NY, USA). P<0.05 was considered statistically significant.

\section{Results}

\section{Zymosan-A exhibited a significant radioprotective effect in vivo}

To prove the radioprotective function of Zymosan-A in vivo, C57BL/6 mice were administered with a total of $50 \mathrm{mg} / \mathrm{kg}$ Zymosan-A 24 and $2 \mathrm{~h}$ before TBI. The results indicated that the survival rates of Zymosan-A group were increased after TBI (Figs. 1A-1D), and the dose reduction factor (DRF) was 1.25 (Zymosan-A vs. NS) (Fig. 1E). These data demonstrated that the TLR2 agonist Zymosan-A exerted a significant radioprotective effect in vivo.

\section{Zymosan-A protected the hematopoietic system against radiation-induced damage}

HE staining was employed to evaluate the radioprotective effect of Zymosan-A on the hematopoietic system. The hematopoietic system damage in the NS group was found to be more severe than that in the Zymosan-A group. The radiation damage on the structure of the

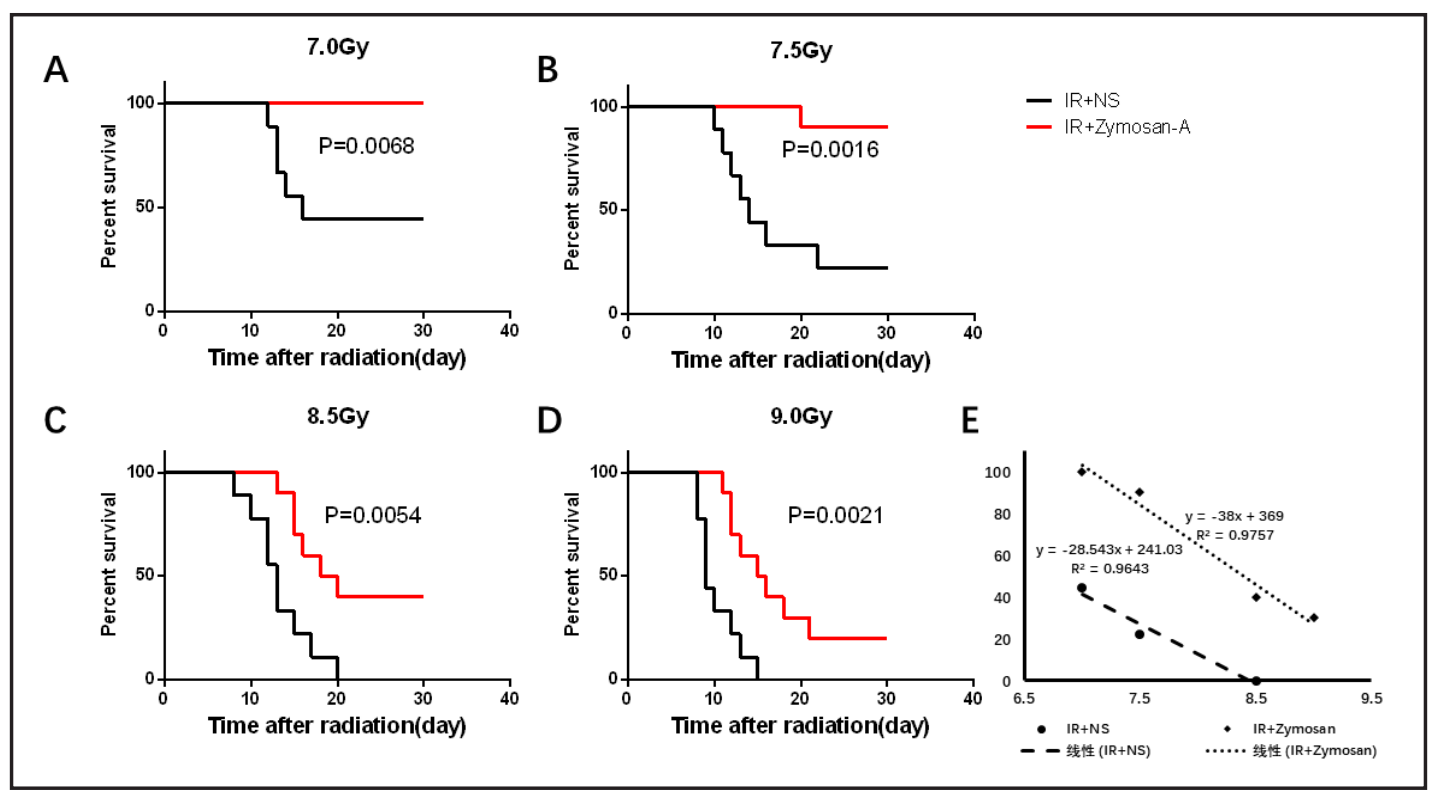

Fig. 1. Zymosan-A showed a significant radioprotective effect in vivo. (A-D) Mice (weighing $18 \mathrm{~g}, 10$ per group) were treated with Zymosan-A (50 mg/kg, dissolved in NS) via peritoneal injection 24 and $2 \mathrm{~h}$ before irradiation and then exposed to 7.0, 7.5, 8.5, or 9.0 Gy TBI. The control mice were treated with NS. The survival was recorded. (E) Linear regression analysis of the survival rate for the mice treated with Zymosan-A or NS post-irradiation. DRF was 1.25 .

\section{KARGER}




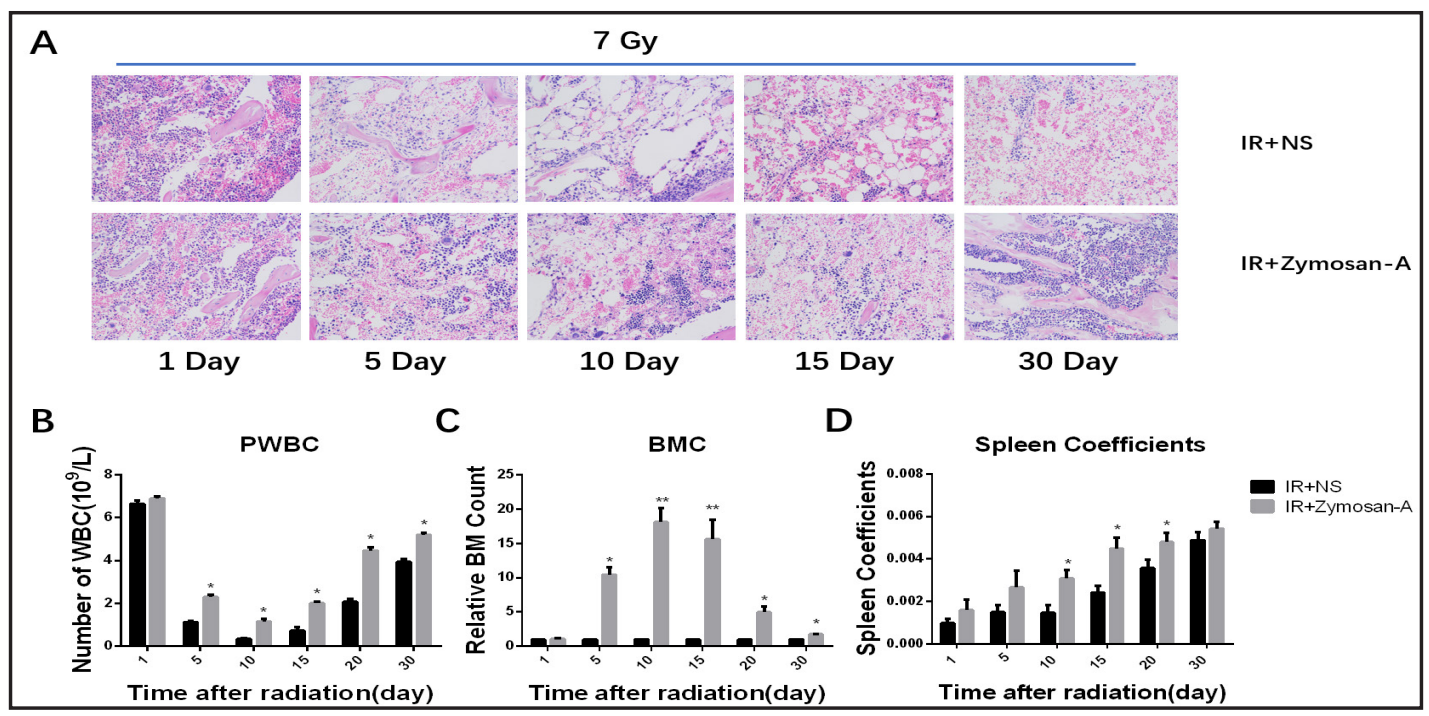

Fig. 2. Zymosan-A protected the hematopoietic system against radiation-induced toxicity. (A) After TBI at 7.0 Gy, the mice were killed by cervical dislocation, and the femur was collected and stained with HE at Days 1, 5, 10, 15, and 30 post-TBI. All images were 200× magnified. The Fig. presents a typical HE image of 3 independent experiments. (B) The number of PBMCs 1, 5, 10, 15, and 30 d post-TBI was determined. (C) The number of BMCs 1, 5, 10, 15, and 30 d post-TBI was determined. (D) The spleen coefficients 1, 5, 10, 15, and 30 post-TBI were calculated. ${ }^{*} \mathrm{P}<0.05$, ${ }^{* *} \mathrm{P}<0.01$.

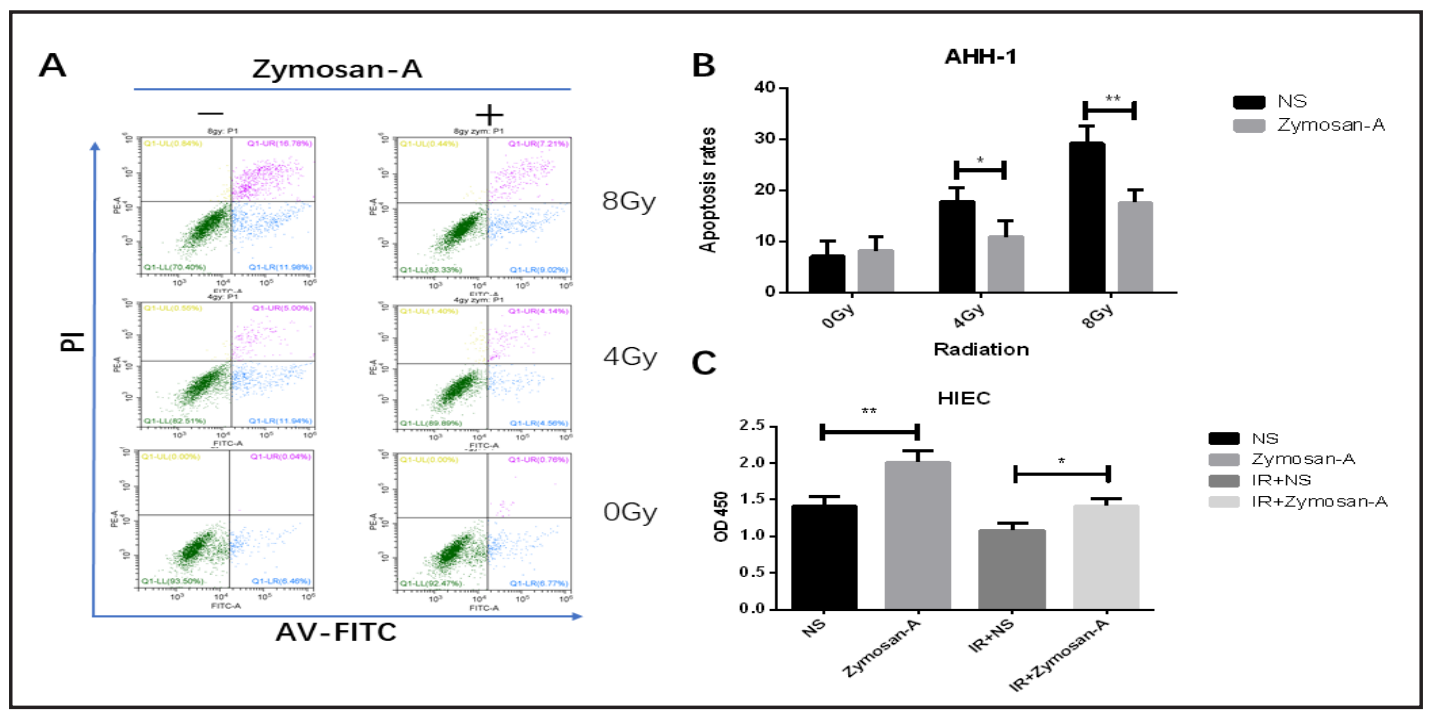

Fig. 3. Zymosan-A promoted cell viability and inhibited cell apoptosis caused by radiation. (A) Cells were treated with Zymosan-A ( $40 \mu \mathrm{g} / \mathrm{mL}) 12$ and $2 \mathrm{~h}$ before radiation. Cells stained with AV-FITC and PI were analyzed by flow cytometry $24 \mathrm{~h}$ post-radiation ( 4 and $8 \mathrm{~Gy}$ ). (B) Data are presented as mean \pm SD of 3 independent experiments. (C) Cells were treated with Zymosan-A ( $40 \mu \mathrm{g} \mathrm{g} / \mathrm{ml}) 12$ and $2 \mathrm{~h}$ before radiation and then counted using CCK-8 assay at $450 \mathrm{~nm}$ post-radiation. ${ }^{*} \mathrm{P}<0.05,{ }^{* *} \mathrm{P}<0.01$.

bone marrow was alleviated in the Zymosan-A group. The number of nucleated cells was greater in the Zymosan group than in the NS group. Moreover, the bone marrow recovered much faster in the Zymosan-A than in the NS group (Fig. 2A). We also found that treatment with Zymosan-A increased the number of PWBCs, BMCs, and spleen coefficients (Figs. 2B2D). Combined, these data indicated that Zymosan-A protected the hematopoietic system against radiation-induced damage, potentially inducing death in mice post-radiation.

\section{KARGER}




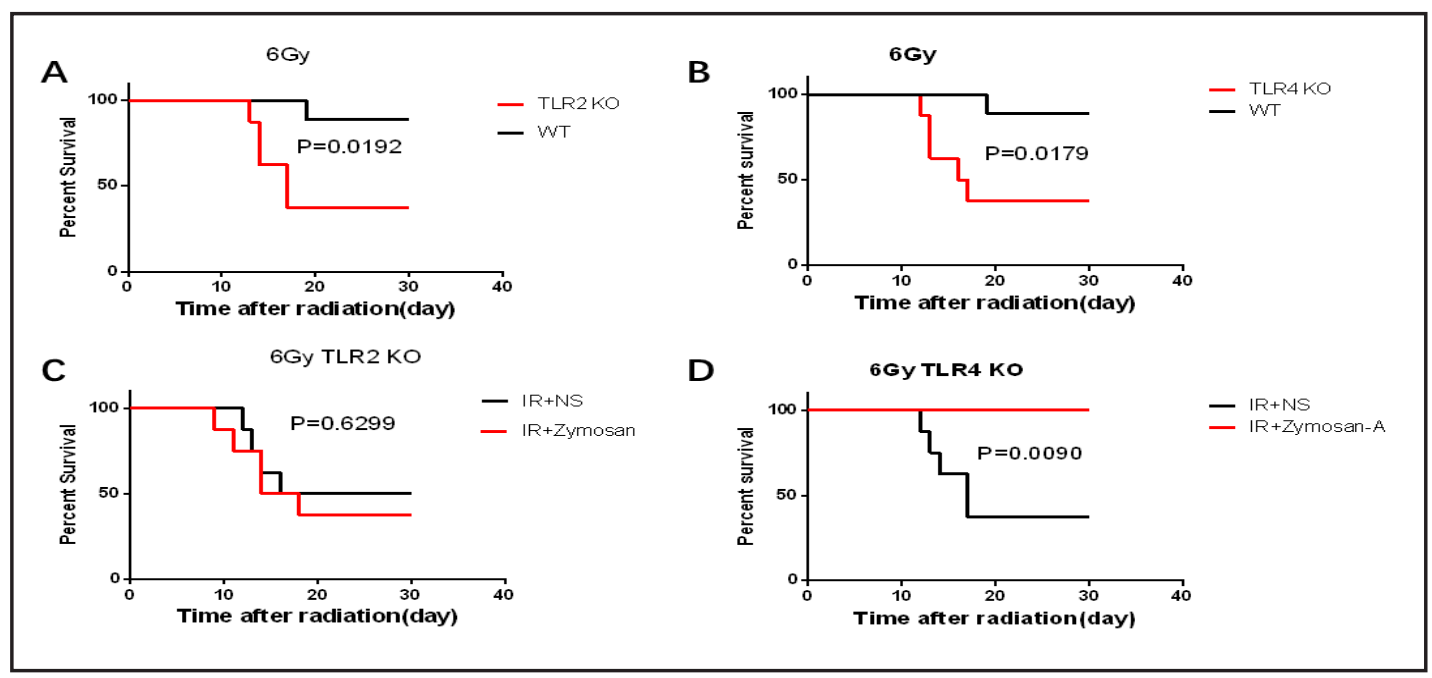

Fig. 4. Zymosan-A induced radioprotective effects via TLR2. (A and B) WT, TLR2-/- and TLR4-/- mice were exposed to 6.0 Gy TBI, and their survival rates were recorded. (C and D) WT, TLR2-/-, and TLR4-/- mice (weighing $18 \mathrm{~g}$, 8 per group) were treated with Zymosan-A ( $50 \mathrm{mg} / \mathrm{Kg}$, dissolved in NS) or NS via peritoneal injection 24 and $2 \mathrm{~h}$ before irradiation and then exposed to $6.0 \mathrm{~Gy}$ TBI. The survival rates were recorded.

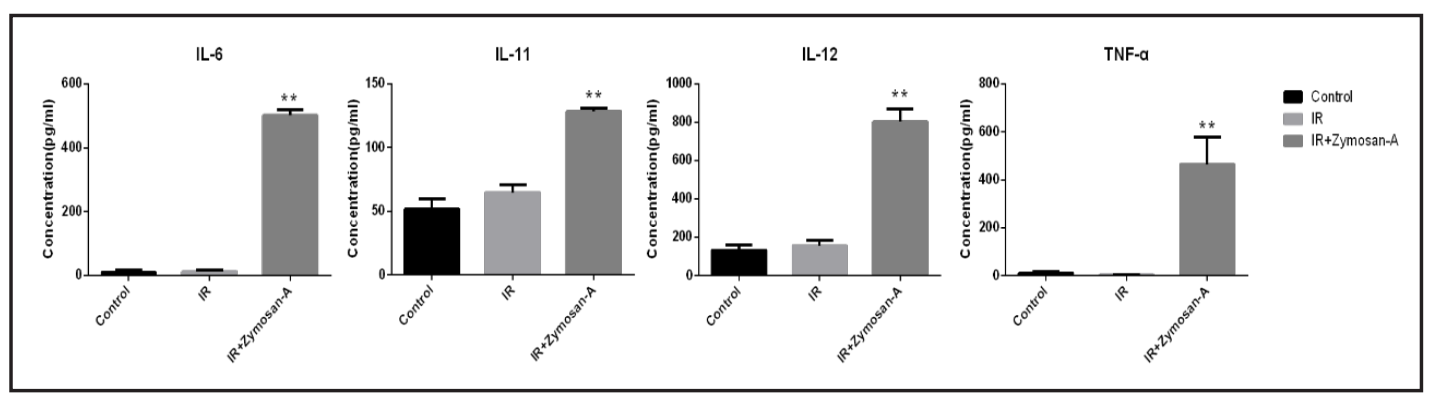

Fig. 5. Zymosan-A upregulated IL-6, IL-11, IL-12, and TNF- $\alpha$ in vivo. IL-6, IL-11, IL-12, and TNF- $\alpha$ were detected by ELISA $24 \mathrm{~h}$ post-irradiation. Data were presented as the mean \pm SD of 3 independent experiments. ${ }^{*} \mathrm{P}<0.05,{ }^{* *} \mathrm{P}<0.01$.

Zymosan-A promoted cell viability and inhibited cell apoptosis caused by radiation.

To verify the radioprotective function of Zymosan-A in vitro, we assayed the cell viability and apoptosis of HIEC and AHH-1 cell lines $24 \mathrm{~h}$ after radiation ( 4 or $8 \mathrm{~Gy}$ ). We found that Zymosan-A inhibited cell apoptosis in AHH-1 (Figs. 3A-3B) and promoted cell viability in HIEC (8 Gy) (Fig. 3C).

Zymosan-A induced radioprotective effects via TLR2.

In our previous study, we showed that TLR2/4 played critical roles in radioresistance in vivo $[15,16]$. Compared with the WT mice, the TLR2-/- and TLR4-/-mice were more susceptible to radiation-induced deaths (Figs. 4A-4B). Zymosan-A protected TLR4-/- mice from radiation-induced death, but had no radioprotective effects to the TLR2-/- mice (Figs. 4C-4D). These findings consistently indicated that Zymosan-A induced radioprotective effects via TLR2 but not via TLR4.

Zymosan-A upregulated IL-6, IL-11, IL-12, and TNF- $\alpha$ in vivo.

We verified that Zymosan-A induced radioprotective effects via TLR2. To further determine the possible mechanism involved, we detected the serum IL-6, IL-11, IL-12, and 
Fig. 6. Possible mechanism of $\mathrm{Zy}$ mosan-A radioprotection.

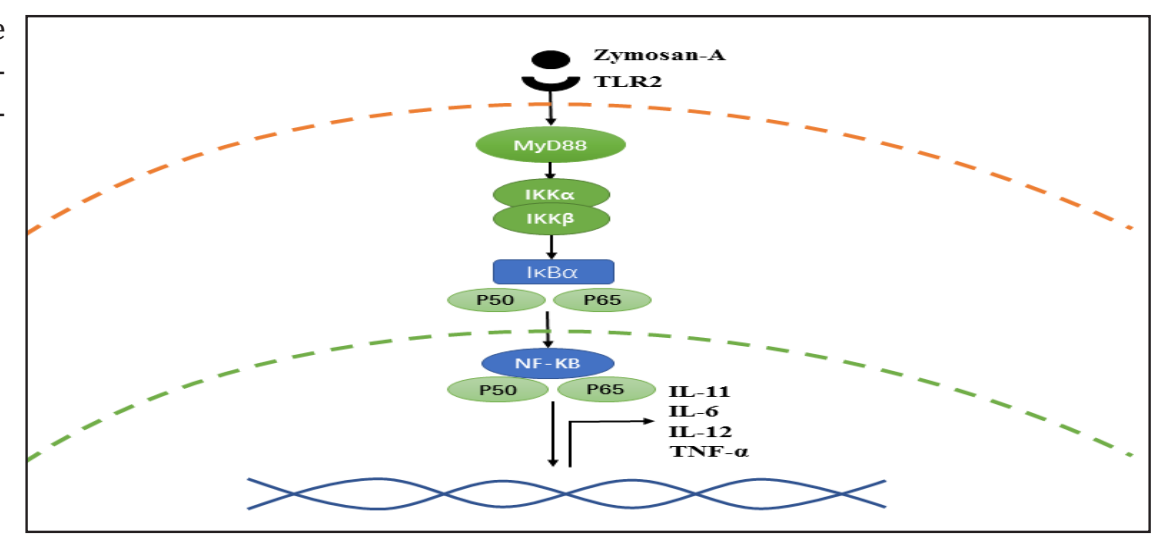

TNF- $\alpha$ levels in the mice pretreated with Zymosan-A; the serum levels of IL-6, IL-11, IL-12 and TNF- $\alpha$ were upregulated in vivo $24 \mathrm{~h}$ post-radiation (Fig. 5).

\section{Discussion}

Many studies indicated that activation of the TLRs signaling pathways can provide protection against radiation-induced damage [14-16, 18, 24, 25]. In our previous studies, we showed that TLR2 and TLR4 played critical roles in radioresistance. TLR2-/- and TLR4-/mice were more susceptible to irradiation-induced mortality and morbidity $[15,16]$.

To the best of our knowledge, this study is the first report to prove that Zymosan-A can protect against radiation-induced damage in vivo and in vitro by targeting TLR2. Zymosan-A, an extract of yeast cell wall, is proven to be a potential agonist of TLR2 [26-28]. After treatment with Zymosan-A, the survival rates of the mice were increased after TBI. HE staining showed that Zymosan-A protected the hematopoietic system against radiation-induced damage, which may lead to death in mice post-radiation. The number of BMC and PWBCs and the spleen coefficients were also increased after treatment with Zymosan-A. By using cultured human cells, we showed that Zymosan-A promoted cell viability and inhibited cell apoptosis caused by radiation. The findings indicated that Zymosan-A protected the hematopoietic system against radiation-induced damage in vivo and in vitro.

To determine the possible mechanism underlying radioprotection by Zymosan- $\mathrm{A}$, we used TLR2-/- and TLR4-/- mice. The results showed that Zymosan-A protected TLR4-/- mice but not TLR2-/- mice from radiation-induced death. These data consistently indicated that Zymosan-A induced radioprotective effects via TLR2 but not TLR4. Many studies indicated that Zymosan-A can induce NF- $\kappa$ B phosphorylation and nuclear translocation by targeting TLR2[21, 22, 29]. Zymosan-A can also upregulate cytokines, including TNF- $\alpha$; the IL-1 family; the IL-6, IL-8, and IL-10 family; IL-11; IL-23; the IL-12 family; IL-15; TGF- $\beta$; and G-CSF[30-34]. In addition, IL-6, IL-11, IL-12, G-CSF, and TNF- $\alpha$ are regarded as radiation protection factors [35-40]. In the current study, we proved that Zymosan-A upregulated the serum levels of IL-6, IL-11, IL-12, and TNF- $\alpha$ in vivo. Our study proved that Zymosan-A exerts marked radioprotective effects in vivo and in vitro by targeting the TLR2 signaling pathway (Fig. 6).

In conclusion, our findings showed that Zymosan-A can provide protection against radiation-induced damage by targeting the TLR2 signaling pathway. These data suggested that Zymosan-A can be a potentially effective radioprotectant.

\section{Acknowledgements}

This study was supported in part by the grants from National Natural Science Foundation of China (No. 81573092 and No. 11635014). 


\section{Cellular Physiology Cell Physiol Biochem 2017;43:457-464 \begin{tabular}{l|l|l|l|}
\hline DOI: 10.1159/000480472 & $\begin{array}{l}\text { (c) } 2017 \text { The Author(s). Published by S. Karger AG, Basel } \\
\text { www.karger.com/cpb }\end{array}$
\end{tabular}

Du et al.: Zymosan-a Protects the Hematopoietic System from Radiation-Induced Damage by Targeting TLR2 Signaling Pathway

\section{Disclosure Statement}

The authors have no interest of conflicts to disclose.

\section{References}

$\checkmark 1$ Barker HE, Paget JT, Khan AA, Harrington KJ: The tumour microenvironment after radiotherapy: mechanisms of resistance and recurrence. Nat Rev Cancer 2015;15:409-425.

2 Baumann M, Krause M, Overgaard J, Debus J, Bentzen SM, Daartz J, Richter C, Zips D, Bortfeld T: Radiation oncology in the era of precision medicine. Nat Rev Cancer 2016;16:234-249.

-3 Herrera FG, Bourhis J, Coukos G: Radiotherapy combination opportunities leveraging immunity for the next oncology practice. CA Cancer J Clin 2017;67:65-85.

4 Farese AM, MacVittie TJ: Filgrastim for the treatment of hematopoietic acute radiation syndrome. Drugs Today (Barc) 2015;51:537-548.

5 Gorbunov NV, Sharma P: Protracted Oxidative Alterations in the Mechanism of Hematopoietic Acute Radiation Syndrome. Antioxidants (Basel) 2015;4:134-152.

6 Atkinson J, Kapralov AA, Yanamala N, Tyurina YY, Amoscato AA, Pearce L, Peterson J, Huang Z, Jiang J, Samhan-Arias AK, Maeda A, Feng W, Wasserloos K, Belikova NA, Tyurin VA, Wang H, Fletcher J, Wang Y, Vlasova, II, Klein-Seetharaman J, Stoyanovsky DA, Bayir H, Pitt BR, Epperly MW, Greenberger JS, Kagan VE: A mitochondria-targeted inhibitor of cytochrome c peroxidase mitigates radiation-induced death. Nat Commun 2011;2:497.

7 Das U, Manna K, Khan A, Sinha M, Biswas S, Sengupta A, Chakraborty A, Dey S: Ferulic acid (FA) abrogates gamma-radiation induced oxidative stress and DNA damage by up-regulating nuclear translocation of Nrf2 and activation of NHEJ pathway. Free Radic Res 2017;51:47-63.

-8 Haghparast A, Mansouri K, Moradi S, Dadashi F, Eliasi S, Sobhani M, Varmira K: Radioprotective effects of lentil sprouts against X-ray radiation. Res Pharm Sci 2017;12:38-45.

-9 Mangoni M, Sottili M, Gerini C, Desideri I, Bastida C, Pallotta S, Castiglione F, Bonomo P, Meattini I, Greto D, Cappelli S, Di Brina L, Loi M, Biti G, Livi L: A PPAR-gamma agonist protects from radiation-induced intestinal toxicity. United European Gastroenterol J 2017;5:218-226.

10 Wang S, Zhang H, Wang A, Huang D, Fan J, Lu L, Chen X: PHLDA1 Promotes Lung Contusion by Regulating the Toll-Like Receptor 2 Signaling Pathway. Cell Physiol Biochem 2016;40:1198-1206.

-11 Chen S, Zhang L, Xu R, Ti Y, Zhao Y, Zhou L, Zhao J: TheBDKRB2 + 9/-9 Polymorphisms Influence ProInflammatory Cytokine Levels in Knee Osteoarthritis by Altering TLR-2 Expression: Clinical and in vitro Studies. Cell Physiol Biochem 2016;38:1245-1256.

12 Zheng Q, Cui G, Chen J, Gao H, Wei Y, Uede T, Chen Z, Diao H: Regular Exercise Enhances the Immune Response Against Microbial Antigens Through Up-Regulation of Toll-like Receptor Signaling Pathways. Cell Physiol Biochem 2015;37:735-746.

13 Yang S, Li F, Jia S, Zhang K, Jiang W, Shang Y, Chang K, Deng S, Chen M: Early secreted antigen ESAT-6 of Mycobacterium Tuberculosis promotes apoptosis of macrophages via targeting the microRNA155-SOCS1 interaction. Cell Physiol Biochem 2015;35:1276-1288.

14 Burdelya LG, Krivokrysenko VI, Tallant TC, Strom E, Gleiberman AS, Gupta D, Kurnasov OV, Fort FL, Osterman AL, Didonato JA, Feinstein E, Gudkov AV: An agonist of toll-like receptor 5 has radioprotective activity in mouse and primate models. Science 2008;320:226-230.

15 Gao F, Zhang C, Zhou C, Sun W, Liu X, Zhang P, Han J, Xian L, Bai D, Liu H, Cheng Y, Li B, Cui J, Cai J, Liu C: A critical role of toll-like receptor 2 (TLR2) and its' in vivo ligands in radio-resistance. Sci Rep 2015;5:13004.

-16 Liu C, Zhang C, Mitchel RE, Cui J, Lin J, Yang Y, Liu X, Cai J: A critical role of toll-like receptor 4 (TLR4) and its' in vivo ligands in basal radio-resistance. Cell Death Dis 2013;4:e649.

17 Zhang C, Zheng M, Zhu XH, Li S, Ni J, Li BL, Liu H, Gao F, Cai JM: Protective effect of CpGoligodeoxynucleotides against low- and high-LET irradiation. Cell Physiol Biochem 2014;34:1663-1674.

18 Chen Y, Xu Y, Du J, Guo J, Lei X, Cui J, Liu C, Cheng Y, Li B, Gao F, Ju J, Cai J, Yang Y: Radioprotective Effects of Heat-Killed Mycobacterium Tuberculosis in Cultured Cells and Radiosensitive Tissues. Cell Physiol Biochem 2016;40:716-726.

$>19$ Takeuchi O, Akira S: Toll-like receptors; their physiological role and signal transduction system. Int Immunopharmacol 2001;1:625-635.

20 Volman TJ, Hendriks T, Goris RJ: Zymosan-induced generalized inflammation: experimental studies into mechanisms leading to multiple organ dysfunction syndrome. Shock 2005;23:291-297. 


\section{Cellular Physiology Cell Physiol Biochem 2017;43:457-464 \begin{tabular}{l|l|l|l|l}
\hline DOI: 10.1159/000480472 2017 The Author(s). Published by S. Karger AG, Basel & and Biochemistry
\end{tabular}

Du et al.: Zymosan-a Protects the Hematopoietic System from Radiation-Induced Damage by Targeting TLR2 Signaling Pathway

-21 Fan X, Zhu JY, Sun Y, Luo L, Yan J, Yang X, Yu J, Tang WQ, Ma W, Liang HP: Evodiamine Inhibits ZymosanInduced Inflammation In vitro and In vivo: Inactivation of NF-kappaB by Inhibiting IkappaBalpha Phosphorylation. Inflammation 2017;10.1007/s10753-017-0546-0

-22 Pan Q Cai J, Peng Y, Xiao H, Zhang L, Chen J, Liu H: Protective effect of a novel antibody against TLR2 on zymosan-induced acute peritonitis in NF-kappaB transgenic mice. Am J Transl Res 2017;9:692-699.

-23 Park BK, Chun E, Choi JJ, Shin Y, Kho YT, Oh SH, Kim SY, Lee TH, Kim TW, Shin E, Do SG, Jin M: Administration of Wasabia koreana Ameliorates Irritable Bowel Syndrome-Like Symptoms in a ZymosanInduced Mouse Model. J Med Food 2017;10.1089/jmf.2016.3844

24 Liu C, Gao F, Li B, Mitchel RE, Liu X, Lin J, Zhao L, Cai J: TLR4 knockout protects mice from radiation-induced thymic lymphoma by downregulation of IL6 and miR-21. Leukemia 2011;25:1516-1519.

-25 Li B, Zhang C, He F, Liu W, Yang Y, Liu H, Liu X, Wang J, Zhang L, Deng B, Gao F, Cui J, Liu C, Cai J: GSK-3beta inhibition attenuates LPS-induced death but aggravates radiation-induced death via down-regulation of IL-6. Cell Physiol Biochem 2013;32:1720-1728.

26 Farnebo L, Shahangian A, Lee Y, Shin JH, Scheeren FA, Sunwoo JB: Targeting Toll-like receptor 2 inhibits growth of head and neck squamous cell carcinoma. Oncotarget 2015;6:9897-9907.

27 Manoharan I, Hong Y, Suryawanshi A, Angus-Hill ML, Sun Z, Mellor AL, Munn DH, Manicassamy S: TLR2dependent activation of beta-catenin pathway in dendritic cells induces regulatory responses and attenuates autoimmune inflammation. J Immunol 2014;193:4203-4213.

$28 \mathrm{Wu}$ J, Zhang Y, Xin Z, Wu X: The crosstalk between TLR2 and NOD2 in Aspergillus fumigatus keratitis. Mol Immunol 2015;64:235-243.

29 Li JT, Wang WQ, Wang L, Liu NN, Zhao YL, Zhu XS, Liu QQ, Gao CF, Yang AG, Jia LT: Subanesthetic isoflurane relieves zymosan-induced neutrophil inflammatory response by targeting NMDA glutamate receptor and Toll-like receptor 2 signaling. Oncotarget 2016;7:31772-31789.

-30 Liu Y, Li J, Liu Y, Wang P, Jia H: Inhibition of zymosan-induced cytokine and chemokine expression in human corneal fibroblasts by triptolide. Int J Ophthalmol 2016;9:9-14.

-31 Holmlund U, Cebers G, Dahlfors AR, Sandstedt B, Bremme K, Ekstrom ES, Scheynius A: Expression and regulation of the pattern recognition receptors Toll-like receptor- 2 and Toll-like receptor- 4 in the human placenta. Immunology 2002;107:145-151.

-32 Schaefer TM, Desouza K, Fahey JV, Beagley KW, Wira CR: Toll-like receptor (TLR) expression and TLRmediated cytokine/chemokine production by human uterine epithelial cells. Immunology 2004;112:428436.

-33 Soria-Castro I, Krzyzanowska A, Pelaez ML, Regadera J, Ferrer G, Montoliu L, Rodriguez-Ramos R, Fernandez M, Alemany S: Cot/tpl2 (MAP3K8) mediates myeloperoxidase activity and hypernociception following peripheral inflammation. J Biol Chem 2010;285:33805-33815.

34 Shi Q Yin Z, Liu P, Zhao B, Zhang Z, Mao S, Wei T, Rao M, Zhang L, Wang S: Cilostazol Suppresses IL-23 Production in Human Dendritic Cells via an AMPK-Dependent Pathway. Cell Physiol Biochem 2016;40:499508.

-35 Krivokrysenko VI, Shakhov AN, Singh VK, Bone F, Kononov Y, Shyshynova I, Cheney A, Maitra RK, Purmal A, Whitnall MH, Gudkov AV, Feinstein E: Identification of granulocyte colony-stimulating factor and interleukin- 6 as candidate biomarkers of CBLB502 efficacy as a medical radiation countermeasure. J Pharmacol Exp Ther 2012;343:497-508.

36 Patchen ML, Fischer R, MacVittie TJ: Effects of combined administration of interleukin-6 and granulocyte colony-stimulating factor on recovery from radiation-induced hemopoietic aplasia. Exp Hematol 1993;21:338-344.

37 Jiang S, Shen X, Liu Y, He Y, Jiang D, Chen W: Radioprotective effects of Sipunculus nudus L. polysaccharide combined with WR-2721, rhIL-11 and rhG-CSF on radiation-injured mice. J Radiat Res 2015;56:515-522.

38 Uemura T, Nakayama T, Kusaba T, Yakata Y, Yamazumi K, Matsuu-Matsuyama M, Shichijo K, Sekine I: The protective effect of interleukin-11 on the cell death induced by X-ray irradiation in cultured intestinal epithelial cell. J Radiat Res 2007;48:171-177.

-39 Wang RJ, Peng RY, Gao YB, Chang GM, Xu XP, Fu KF, Luo QL: [Jak/STAT signaling pathway of IL-11 in the protection of intestinal epithelial cells from neutron radiation]. Xi Bao Yu Fen Zi Mian Yi Xue Za Zhi 2009;25:27-30.

-40 Xiong GL, Zhao Y, Xing S, Shen X, Ning XC, Lu SX, Li J, Guo LL, Hao R, Chen TC, Miao JL, He JC, Luo QL: [Radiation protection effect of rhIL-12 on monkey hematopoietic system]. Zhongguo Shi Yan Xue Ye Xue Za Zhi 2013;21:150-154. 